\title{
UM NÓ DE SANGUE NA GARGANTA: A EXPERIÊNCIA DO POEMA EM HERBERTO HELDER
}

Erick Gontijo Costa*

RESUMO: Este texto investiga a obra de Herberto Helder, sob a perspectiva da experiência de escrita, enfocando as seguintes noções em seus poemas: leitura, tradução, nascer da escrita corpo e paisagem.

PALAVRAS-CHAVE: experiência; leitura; tradução; corpo; paisagem.
* erickgcosta@gmail.com

* Delch UFM.

RÉSUMÉ: Ce texte examine le travail de Herbert Helder, du point de vue de l'expérience d'écriture, en se concentrant sur les concepts suivants dans ses poèmes: la lecture, la traduction, né de l'écriture, le corps et le paysage.

MOTS-CLÉS: I'expérience; la lecture; la traduction; le corps; le paysage. 
e tu que me ouves, leva tudo mas não me leves a mão, e as maneiras que the dou, de assinatura, e nela me refaço com um soluço, autor, nó de corpo, a contar com a autoria

Herberto Helder

\section{LEITURA DO POEMA}

Entre todas as formas de leitura, a do poema é das mais exigentes, visto que nele a linguagem e a vida compõem um nó indiscernível, irredutível à interpretação: amálgama entre vida e linguagem, que tomba fora da representação e de todo senso comum. Só se aproxima do poema, destituindo-se da rigidez dos aparatos prévios de pensamento para, na experiência de leitura, compor outra forma de corpo, de pensamento e de mundo, em que os conceitos entram em metamorfose, gerando aberturas no sistema de que derivam. Ninguém que, de fato, tenha lido um poema sai o mesmo dessa experiência. Há um aforismo de Kafka que diz: "A partir de certo ponto não há mais retorno. É este o ponto que tem de ser alcançado." ${ }^{1} \mathrm{O}$ poema é um ponto sem retorno, capaz de modificar corpo, pensamento e mundo, ao recriá-los.

No livro A poesia ensina a cair, Eduardo Prado Coelho se dedica ao exercício de escrever ensaios sobre poesia, pensando modos possíveis de aproximação da crítica ao poema. Seu método é "deixar que duas línguas se tornem cúmplices e acabem por formar uma só linguagem."2 Em um dos textos do mesmo livro, "Como uma corda de alegria", Coelho formula duas premissas para a leitura da obra do autor que aqui nos interessa - Herberto Helder. A primeira é que essa obra se lê por incisões, "cortes encurvados para o lado negro em que cada coisa se silencia"3. Modo interessante de abordagem de um sistema textual que tende à amplificação contínua de relações internas entre suas imagens, pois parece estancar a proliferação de significados do texto para nele perceber os movimentos estruturantes da obra e as energias que ali circulam. A segunda é a necessidade de se "abandonar drasticamente os códigos da verossimilhança, ou mesmo os meios de representação (não há modelação, mas modulação)"4. Desde a modernidade, a poesia (tal como algumas literaturas) tende a abolir o mecanismo de referenciação da linguagem a um suposto exterior, ao qual tenta representar eficazmente, para se voltar, em movimento circular, para si mesma, referenciando-se a si e, assim, se tornando toda ela uma imagem, ou, ainda, entrando numa espécie de devir não-referencial ${ }^{5}$. Mas interessa-me, dentre outros aspectos dessa obra, aproximar do mecanismo não representativo de $\mathrm{HH}^{6}$ e nele perceber o que de singular há, e, não tanto, aprofundar a discussão a respeito da mímesis e sua negação ou ausência.

Importa, portanto, perceber o ponto em que o poema mais silencia do que significa, caso se pretenda dizer algo a partir dele e não apenas permanecer fechado em seus jogos
3. COELHO. A poesia ensina a cair, p. 17.

4. COELHO. A poesia ensina a cair, p. 17.

5. Maurice Blanchot, na nota 3 Espaço literário formula da Espaço literário, formula da seguinte maneira a questáo modernidade: "Será que modernidade: "Será que a própria linguagem não se torna, uma linguagem que cort uma linguagem que conteria em figura mas que a realidade em figura, mas que seria a sua propria imagem, imagem da linguagem - e nấo linguagem figurada - ou ainda linguagem imaginária, linguagem que ninguém fala, ou seja, que se fala a partir de sua própria ausência tal como a imagem aparece sobre a ausência da coisa, linguagem que se dirige também à sombra dos acontecimentos, não à sua realidade, e pelo fato de que as palavras que os exprimem não são signos mas imagens, imagens de palavras e palavras onde as coisas se fazem imagens?" (BLANCHOT. O espaço literário, p. 25.)

6. Utilizarei, ao longo do texto apenas as iniciais $\mathrm{HH}$ para Herberto Helder.
EM TESE
BELO HORIZONTE
v. 21
N. 3
SET.-DEZ. 2015
COSTA. Um nó de sangue na garganta [...]
P. $10-26$ 
7. HELDER. Photomaton \& Vox, $\mathrm{p}$. 136.

8. COELHO. A poesia ensina a cair, p. 17.

9. HELDER. Photomaton \& Vox, p. 133 de significação. Dita a primeira palavra, instaura-se a alternância entre silêncio e som, ou seja, entra-se no ritmo, condutor de forças corpóreas do poema: "A coerência dos meus poemas é a coerência da energia" , dirá HH. Se a coerência é energética, falar em termos de ritmo é "promover forças, capturar energias, canalizar vertigens, entrar na corrente, nos fluxos vitais, nas inclinações irreversíveis e fatais." Procuro, aqui, mapear, esboçar a dinâmica rítmica, condutora de energias que animam o poema. Deixar que o poema, com sua maquinaria rítmica, conduza um pensamento, uma leitura capaz de captar as marcas da experiência de sua escrita. Porque lá, "Implantado no meio das leituras, o poema funciona em estado de máquina vital."

\section{NASCER DO POEMA}

O uso cotidiano da linguagem representativa organiza-se pela linearidade temporal imposta pela sintaxe gramatical pela delimitação de entradas possíveis no texto. Mas, na poesia de $\mathrm{HH}$, ampliam-se as vias de leitura, já que os lugares do leitor não se demarcam de antemão. Entra-se por qualquer ponto do espaço textual, pois não há linearidade. Cabe ao leitor, por um lado, certo abandono ao fluxo incessante e incontornável do escrito e, por outro, alguma escolha de percurso.

Se se entra nessa obra é, principalmente, mas não apenas, pela captura de um fluxo: o do ritmo. Por ritmo entendo, aqui, a contínua "modulação da voz" exercida no ofício do poema. Silvina Rodrigues Lopes, em ensaio fundamental, escrito a partir da obra de $\mathrm{HH}$, de nome $A$ inocência do devir, dirá que os poemas em questão modulam continuamente (e não moldam, o que seria dar acabamento) voz e silêncio, criando tensões semânticas e rítmicas, isto é, tensões entre a multiplicidade de sentidos e "o timbre, os acentos, as intensidades" ${ }^{10}$ Assim, o leitor será levado pela continuidade do poema, transitando entre as escanções de texto em texto que cada livro concretiza.

É preciso cautela quando se adentra em uma poética como a de HH, caso não se pretenda apenas repetir, num gesto de fascínio, o que já lá está escrito. Mas, sem algum fascínio e possessão rítmica pelo texto, o processo de leitura tende a interromper-se. Assim, escolho, entre o sistema reticular dessa poesia, um nó, um norte: "um nó de sangue na garganta,/ um nó apenas duro"11. Voz e sangue, um grão da voz ${ }^{12}$, um nó: o da experiência de escrita, em que a vida se traça no livro que a morte contínua, pouco a pouco, devora:

traças devoram as linhas linha a linha dos livros, o medo devora os dias dia a dia das vidas,

a idade exasperada é ir investindo nela:

a morte no gerúndio ${ }^{13}$
10. LOPES. A inocência do devir - Ensaio a partir de Herberto Helder, p. 60.

11. HELDER. A morte sem mestre p. 9-10.

12. Refiro-me ao conceito barthesiano de "grão da voz", que aqui nos auxilia para pensar a de toque musical: "espaço (gênero) muito preciso onde (genero) muito preciso onde uma lingua encontra uma voz. Darei imediatamente um nome a esse significante ao nivel do qual, creio eu, a tentaçáo do ethos pode desaparecer - $e$, consequentemente, o adjetivo pode ser dispensado: será o 'grão': o grão da voz, quando a voz tem uma postura dupla, uma produção dupla: de língua e de música." (BARTHES. O óbvio e o obtuso, p. 238.

13. HELDER. Servidões, p. 693. 
14. LOPES. A inocência do devir Ensaio a partir de Herberto Helder, p. 29.

15. LOPES. A inocência do devir - Ensaio a partir de Herberto Helder, p. 18
A experiência, que é "ofício de viver, o ofício de arrancar à morte a vida" ${ }^{14}$, é também ofício de morrer. A vida que se extrai da morte não é uma categoria, digamos assim, puramente positiva, independente. Não há, na poesia de $\mathrm{HH}$, trabalho de vida sem trabalho de morte. A vida, que se afirma na construção de um corpo textual, é passagem de um estado em que a morte, substantivo comum a todos, se dessubstancia em ação contínua de morrer, vai-se morrendo linha linha, como quem renasce a todo tempo. Porque o poema é ritmo, pensamento e ato constitutivo de um corpo textual.

Ainda sobre a experiência, é preciso acrescentar: não me refiro a um acúmulo do conhecimento, resultante da elaboração do vivido. Não há, nessa acepção, referência a nada que se construa de modo definitivo, acabado. Antes: a cada escrita de um poema, refazer o corpo, renascer. A cada vez, ascender à altura do nome.

A obra, por ser ato constitutivo e, não, apenas representativo, ao ser criada, cria aquele que escreve, confere-lhe um corpo: "Enquanto pensamento, o poema é acima de tudo um lugar ou um modo de nascer. Ou mais propriamente, o poema é o nascimento do poema, engendrado através do en trançado que nele se faz e se desfaz incessantemente" ${ }^{\prime 1}$.

A cena de nascimento do poema e de um corpo (orgânico) entrançados, atados aos símbolos e às imagens textuais, refaz-se incessantemente nos livros. Nascimento do corpo do poema engendrado pelo próprio poema. Em Do Mundo, as nuances da existência poética precisam-se:

Selaram-no com um nó vivo como se faz a um odre,

ele, o dos membros trançados, o recôndito.

Podiam arrancá-lo aos limbos, à virgindade, ao pouco,

destrançá-lo

para o potente e o suave mundo:

as ramas de leite que se devoram

sal e mel que se devoram,

pão, o alimento ígneo,

testa lavorada pela estrela saída agora da forja.

Custara-lhe que a cabeça e os membros atravessassem a vagina materna.

Mas depois os dois lados da cabeça refulgiram muito, e ele ergueu-se à altura do seu nome,

antebraços apanhando a luz, pés a correr como em cima da água, torso puro: algures, algo.

E então selaram-no, e à púrpura nele, e à música jubilatória dos tubos na boca,

nó de couro num odre vivo,

a frescura como uma chaga:

louco, bêbado. E selado

luzia ${ }^{16}$ p. 131 
17. O nome próprio do autor é Luís Bernardes de Oliveira. Seu nome de escrita é outro: Herberto Helder. Assinatura nascida da experiência de escrita, podemos pensar.

18. BLANCHOT. A parte do fogo, p. 101.
O gesto de escrever como quem entrança um corpo para destrançá-lo, arrancá-lo à morte, ao limbo, lugar de indefinição onde ainda não se chega a se constituir como canto, permite ao corpo escrito erguer-se à altura do seu nome de escrita ${ }^{17}$. Sela-se o corpo com um nó entre corpo orgânico, imagem e símbolo: "nó de couro num odre vivo". Permanece, no entanto, uma chaga, de onde brota a verdade daquele que escreve: a chaga, como marca originária de um corpo, permitindo-lhe luminosa existência em seu devir-escrito. Corpo e chaga como nó entre potências de morte e de vida, na reversibilidade de uma força a outra.

Em A parte do fogo, livro de Maurice Blanchot, cujo pensamento ressoa nos poemas de $\mathrm{HH}$, há indicações de uma paradoxal inversão quanto à precedência da autoria em relação à obra:

O poeta nasce pelo poema que ele cria; ele é o segundo, em vista do que faz; é posterior ao mundo que criou e em vista do qual suas relações de dependência reproduzem todas as contradições expressas nesse paradoxo. O poema é sua obra, o movimento mais verdadeiro de sua existência, mas o poema é o que o faz ser, o que deve existir sem ele e antes dele, numa consciência superior onde se unem o escuro do fundo da terra e a claridade de um universal poder de fundar e justificar ${ }^{18}$.
A existência do autor, segundo essa lógica, resulta do poema, só há ser em face da criação. Sem a criação, há falta de ser. Refiro-me, aqui, à elaboração lacaniana de "manque-à-être”. De modo abreviado, pode-se entender por essa lógica que o sujeito lacaniano é marcado por inconsistência desde sua origem. Mas, em face de um objeto a ser produzido artesanalmente, a partir de certa consistência lógica, o objeto-a (resíduo corporal inominável restante da entrada de um corpo na linguagem, operador da causa de seu desejo), um sujeito poderá constituir-se pontualmente. $\mathrm{O}$ ato de escrita pode ser pensado como um modo de um sujeito chegar a existir em face da escrita. A escrita como causa de seu desejo e, consequentemente, de existência, em seu devir-obra ${ }^{19}$.

Acompanhando essa lógica e perseguindo os rastros da experiência na poética de $\mathrm{HH}$, chega-se, pouco a pouco, ao entendimento do ofício de escrita não apenas como gesto primeiro, do qual decorre uma autoria. A escrita é ato de composição do corpo, do poema e de um mundo ou paisagem do poema, simultaneamente. Poema e poeta criando-se mutuamente, na tensão da sintaxe: "o poema escreve o poeta"20: o poema é escrito pelo poeta, o poeta é escrito pelo poema. Há "autor,/ como se ele mesmo fosse o poema"21.

Em HH, a experiência de escrita e seus efeitos se dão no jogo de composição de símbolos unificadores de potências desordenadas. Em Os passos em volta, livro de narrativas
19. A respeito, ver: C. acurar-se da escrita.

20. HELDER. Do Mundo. In: $A$ fac não corta o fogo, p. 133.

21. HELDER Do Mundo In: $A$ faca não corta o fogo, p. 132. 
biográficas - se entendermos que a biografia de HH é a biografia da obra, no sentido de que só há a vida escrita -, a operação de escrita como ordenadora das potências se depura como estilo:

O estilo é um modo subtil de transferir a confusão e violência da vida para o plano mental de uma significação. Faço-me entender? Não? Bem, não aguentamos a desordem estuporada da vida. E então pegamos nela, reduzimo-la a dois ou três tópicos que se equacionam. Depois, por meio de uma operação intelectual, dizemos que esses tópicos se encontram no tópico comum, suponhamos, do Amor ou da Morte ${ }^{22}$.

A confusão e a violência, equacionadas em tópicos, constituem-se em símbolos condensadores e organizadores em meio à desordem das potências (ou pulsões, tais como pensadas por Freud) de morte e de vida. O poema equaciona, por via da centralização que a ordem simbólica permite, a experiência atravessada por vida e morte. O estilo é, portanto, um recurso contra o terror, "o terror que há sempre/ no fundo informulado de uma vida"23. Entretanto, a experiência de criação, além de consistir em um jogo simbólico, salvaguarda daquele que escreve, é um modo de veicular a morte de palavra em palavra, porque "a morte passa de boca em boca/ com a leve saliva"24. Se por um lado tem como efeito o nascimento, é por outro um ofício moribundo, sem anulação possível entre esses movimentos contrários presentes no poema. Morte e vida, jogando-se simultaneamente, participam no ofício do canto, o qual se constitui às voltas com o terror que ecoa do "fundo informulado de uma vida".

A partir do pensamento de Gilles Deleuze, em seu texto "A imanência: uma vida...", podemos desdobrar um pouco mais a questão da vida que se atualiza no poema, em seu fundo informulado:

Entre sua vida e sua morte, há um momento que não é mais do que este de uma vida jogando com a morte. A vida do indivíduo deu lugar a uma vida impessoal, entretanto singular, que desprende um puro acontecimento livre dos acidentes da vida interior e exterior, isto é, da subjetividade e da objetividade do que acontece. Homo tantum ${ }^{25}$ do qual todo mundo se compadece e que alcança alguma beatitude. É uma hecceidade ${ }^{26}$, que não é mais de individuação, mas de singularização: vida de pura imanência, neutra, além do bem e do mal, já que só o sujeito que a encarna em meio às coisas a torna boa ou má. A vida de tal individualidade se apaga em proveito da vida singular imanente a um homem que não tem mais nome, embora não se confunda com nenhum outro. Essência singular, uma vida... ${ }^{27}$

Nesse fragmento, Deleuze trabalha com a noção de uma vida impessoal, que se desprende da vida do indivíduo e pode
25. Uma possível tradução seria "homem tão-somente".

26. Uma possível tradução seria "estidade", evocando o neutro de terceira pessoa: o "ele sem rosto", diríamos com Blanchot.

27. No original, lê-se: “Entre sa vie et sa mort, il y a un moment qui n'est plus que celui d'une de l'individu a fait place à une vie impersonne fact place une sie impersonnelle, et pourtant singulière, qui dégage un pur evenement libéré des accidents de la vie interieure et exterieure, de I'objectivité de ce qui arrive. $<<$ Homo tantum $>>$ auqui tout le mond compatit tout le monde compattit et qui C'est une hecceité, qui n' plus d'individuation, qui n'est singularisation: vie de pure immanistion. vie de pure immanence, neutre, au-dela du bien et du mal, puisque seul sujet qui l'incarnait au milieu les choses la rendait bonne individuatín s'effece telle individualite s'efface au profit de homme qui n' plus de ne à homme qui n'a plus de nom, bie qu'il ne se confondre avec aucun autre. Essence singulière, une vie..." (DELEUZE. Philosophie. Tradução de E G C e João Rocha.) 
28. HELDER. Photomaton \& Vox, p. 135.

29. HELDER. Photomaton \& Vox, p. 54 atualizar-se, por exemplo, em um poema, em suas palavras e suas imagens, sem que necessariamente seja encarnada por um sujeito em (des)articulação com um objeto. Uma vida neutra, uma "estidade" imanente, fora da representação, e, não, uma identidade. Homo tantum, homem tão-somente. Vida mínima, singular, informe.

Entretanto, se há vida imanente na poesia de $\mathrm{HH}$, "O poema assenta numa experiência do mundo. A experiência é uma memória em estado de actualidade sensível." ${ }^{28}$ Arrancada à morte, uma vida se atualiza em memória escrita, matéria sensível. Repare-se: estamos distantes do campo das biografias identitárias e nos aproximamos do campo de testemunho de uma experiência neutra. Uma vida atualizada em imagem se desprende, se arranca à experiência de mundo do indivíduo. Há a memória como escrita, matéria sensível, liberta do mundo referencial, canalizando energias corporais no ritmo poético. Nessa experiência de criação, corpo e obra fazem-se num só ato e, nessa perspectiva, só há poema. Corpo, mundo e obra acontecem na linguagem. Exterioridade e interioridade tornam-se um circuito contínuo. "O valor da escrita reside no facto de em si mesma tecer-se ela como símbolo, urdir ela própria a sua dignidade de símbolo. A escrita representa-se a si, e a sua razão está em dar razão às inspirações reais que evoca." ${ }^{29}$ Escrita e experiência de mundo acontecem no plano imanente do poema.
Se se fala em símbolo e representação da escrita por si própria, tornando-se uma substância que se autoengendra, o ogo, no entanto, não é o da verossimilhança. A experiência como memória em estado de atualidade cria tensões entre forças heterogêneas que se encerram no poema, que segue não a coerência de significados ou das leis de um suposto mundo anterior ao escrito, mas a coerência de energias.

A coerência energética não busca estabelecer simetria entre escrita e realidade. Antes, "produz uma tensão muito mais fundamental do que a realidade. É nessa tensão real criada em escrita que a realidade se faz." ${ }^{30} \mathrm{Ou}$ seja: quando se fala em corpo e obra compostos na experiência de escrita, há tensão energética, visto que, no poema, morte e vida operam como símbolos criados e criadores da matéria escrita, continuamente se decompondo e recompondo-se.

Somente no plano do poema, em suas imagens, assinala-se a verdade verificável no poema: a que ele mesmo produz. Ta seria "o talento de saber tornar verdadeira a verdade" 31 da experiência: "Chega a mão a escrever negro e conforme vai escrevendo mais negra se torna"32. A escrita, ao "dar razão às inspirações que evoca”, adensa a experiência por meio da própria experiência, o poema por meio do poema, o mundo por meio do mundo, o corpo por meio do corpo, sua verdade por meio da sua verdade. Resta a mão negra, obra imanente.
30. HELDER. Photomaton \& Vox, p. 54.

31. HELDER. Photomaton \& Vox, p. 55.

32. HELDER. Photomaton \& Vox p. 54-55. 
33. Na tese de doutorado acurarse da escrita - Maria Gabriela Llansol, desenvolvo um estudo mais detalhado sobre os conceitos referidos. (C. acurar-se da escrita.).

\section{CORPO DO POEMA}

A noção de corpo não é simples. Tanto mais complexa é se pensada como corpo textual. Por mais que se queira precisar um conceito para corpo - mesmo que se recorra a dicionários e saberes que tendem à objetividade, como os científicos -, o corpo resta irredutivelmente opaco à linguagem. Conceitos como corpo imaginário, eu, sujeito do inconsciente, voz, olhar, desejo, pulsão e letra, da psicanálise freudiana e lacaniana; potência, das filosofias de Espinosa, Nietzsche e Deleuze; escritura, em Lacan, Derrida e Barthes são imprescindíveis para delinear um esboço do que se pode entender por corpo em sua articulação com a escrita ${ }^{33}$.

Sem explicitar toda a pesquisa necessária para esboçar o que aqui entendo por corpo, mas sem dela abrir mão, poderíamos dizer que um corpo é uma estrutura composta por elementos somáticos, palavras e imagens, articulada a uma paisagem. Um corpo é um edifício de imagens colhidas em outros corpos e na paisagem em que habita. Essas imagens são organizadas, em certa medida, pela linguagem, pela sua potência de nomeação, a qual estabelece uma sintaxe entre as imagens, que delimitam um espaço interior e um exterior, não excludentes, com aberturas de circulação entre dentro fora. A esse edifício especular de imagens entrelaçadas pela linguagem, fortificação que resiste à dissolução entre interioridade e exterioridade, mas assegura a circulação contínua entre uma e outra, podemos nomear eu ou corpo imaginário. Nesse edifício, nos lugares onde a visibilidade (e a consciência) é menor ou inexistente, um sujeito pode habitar à maneira do que aparece e desaparece, sempre que interior e exterior encontram vias comunicantes, isto é, orifícios que não se recobrem no edifício: janelas, portas. Olhos, boca e ouvidos, por exemplo, são vias entre dentro e fora, lugares de condensação e dispersão de energias ou potências. É onde o olhar e a voz têm lugar, entre o corpo e a paisagem, que o poema pode ser lugar de passagem, de circulação e produção de energia. Esse corpo tem também órgãos e sangue. As energias vitais e mortíferas aí circulam, indo da paisagem ao corpo, do corpo à paisagem. Energia pulsional, poderíamos dizer com Freud. A escrita pode ser um modo de contínua decomposição e recomposição desse edifício e pode fazer circular nele as energias. Nesse sentido, escrita e sangue são símbolos corporais ou corpos simbólicos dotados de reversibilidade entre si. "Um nó de sangue na garganta: um nó apenas, duro" - voz, sangue, escrita. Há poema, principalmente, onde corpo e linguagem se enodam, podendo aí haver ou não aparição de um sujeito articulado a objetos:

que um nó de sangue na garganta,

um nó de ar no coração,

que a mão fechada sobre uma pouca de água,

e eu não possa dizer nada, 
34. HELDER. A morte sem mestre, p. $9-10$. e o resto seja só perder de vista a vastidão da terra, sem mais saber de sítio e hora,

e baixo passar a brisa

pelo cabelo e a camisa e a boca toda tapada ao mundo, por cada vez mais frios

o dia, a noite, o inferno, o inverno,

sem números para contar os dedos muito abertos cortados das pontas dos braços,

sem sangue à vista:

só uma onda, só uma espuma entre pés e cabeça,

para sequer um jogo ou uma razão,

oh bela morte num dia seguro em qualquer parte

de gente em volta atenta à espera de nada,

um nó de sangue na garganta,

um nó apenas duro ${ }^{34}$

Um nó de sangue, um nó de ar, um coração, uma mão fechada ante a vastidão da terra: cada elemento, orgânico ou não, é uma imagem cerrada, símbolo sem referenciação a uma realidade exterior à língua. Símbolo tendendo à imanência, dispositivo condensador e dispersor de energias num circuito rítmico que vai do poema ao poema, passando por quem escreve e quem lê. $\mathrm{Na}$ circulação rítmica constitutiva do poema, que, como se, vê opera em campos distintos da metáfora, já que símbolo, nessa poética, não é apenas instrumento de significação, mas principalmente órgão vital do corpo, a escrita se torna "forma concreta, uma forma de vida, nunca uma formulação mental ou ideológica”35. Forma concreta orientada para a contínua modelação do fundo informulado de uma vida:

Trata-se de uma operação, e o que pode tornar-se visível é o modo - sempre arriscado, livre (de inspiração libertária) -, nunca um modelo. Modelações da matéria-prima, sob a força de um pensamento aberto a todos os poderes e solicitações, mas orientado para o final objetivo do domínio da <<coisa >> que está nas coisas. O mundo do espírito é uma organização simbólica e o seu fundamento encontra-se na matéria, no corpo. O espírito deve entender-se como apenas o tecido de alusões simbólicas do próprio corpo. A escrita realiza a circulação do símbolo no plano material; é uma simbologia corporal e também uma corpografia simbólica. Na escrita reside o símbolo do corpo, mas o corpo é a última e verdadeira escrita. O silêncio. ${ }^{36}$

O corpo é a verdadeira escrita, porque no cerne da experiência do poema está o nó entre corpo e língua. No que do corpo resta sem significação e se expressa fora do sentido, porém, por meio da operação poética, na linguagem, está a verdade da experiência de escrita: o silêncio do que não se diz, mas se escreve. Operação que confina com a impossibilidade estruturante da língua: articular em palavras as coisas do mundo (o corpo orgânico ou os objetos, por exemplo). 
37. João Amadeu Oliveira, em $A$ poesia de Herberto Helder, demonstra, na poesia de $\mathrm{HH}$ o desenvolvimento de uma corpo e linguagem, ficandr questão do sujeito, digamo assim, num segundo plano: "Em Herberto Helder, ao contrário de uma consciência de si, una conscies uma consiên centrada bipolarmente no corpo nas palavras: transfere-se 0 cos modernistas para um alma mone filtro ou imo nala poetica, SIIVA A poesia de Herberto Helder - Do contexto ao texto: uma palawr sagrada na noil una palava sagrada a noite do mundo, p. 147.)
Mas, sabemos, em princípio, a palavra, em seu estatuto metafórico, jamais toca as coisas.

Entretanto, diferentemente do drama moderno em torno do sujeito, e aí reside o impulso do poema em $\mathrm{HH}$, há nas palavras o seu tanto de coisa, porque nessa poética corpo e linguagem não se dissociam, antes só se constituem se se articulam em alguma medida ${ }^{37}$. Se a palavra não é capaz de significar a completude do corpo ou das coisas, é, no entanto, um refúgio para o que resiste à nomeação. $\mathrm{O}$ que da significação se subtrai retorna à palavra como ritmo, energia, pulsação corpórea. Assim, podemos dizer que as palavras, no poema, comovem o corpo, movem o corpo junto a si. Há palavra e corpo em forma de nó, um nó vocal. “Um nó de sangue na garganta”. Ou "simbologia corporal", "corpografia simbólica".

\section{PAISAGEM DO POEMA}

Resultante da operação poética de $\mathrm{HH}$, experiência constitutiva de um corpo linguístico, articulam-se em nó energias que excedem a capacidade de nomeação da língua, mas nela e por meio dela animam outra forma de corpo, a do poema. A essa operação, Silvina Rodrigues Lopes nomeia nó corpo-linguagem:

Quando se fala de um nó corpo-linguagem fala-se sempre de uma ligação pela qual se entra em processo de metamorfose.
Daí que um nó seja um ponto de voragem, um umbigo, o lugar onde se manifesta uma energia que não refigura, que estratifica sensações não integráveis no funcionamento orgânico. ${ }^{38}$

Um nó corpo-linguagem permite a metamorfose (e, não, a metáfora) do corpo em símbolo e do símbolo em corpo em constante reversibilidade. Por outro lado, é ponto de voragem, em que a palavra se torna foco captador e dispersor do excedente energético inassimilável pelo corpo orgânico na paisagem do texto. Nó literal ${ }^{39}$ entre corpo, poema e paisagem.

Até aqui, foi investigado o nascimento simultâneo do poema e do corpo na experiência de escrita. Corpo, poema e vida arrancados à morte, a cada escrito. Mas o corpo do poema não existe no nada. Há "um nada de nada, e tudo eximiamente com/ muita força". Paisagem ou "o mundo arrancado aos limbos"40. A rigor, o poema de $\mathrm{HH}$ é ele mesmo uma paisagem entre paisagens:

Ver sempre o poema como uma paisagem. Esta paisagem é dinâmica. Preocupa-me a natureza do solo, por isso me imponho certa unidade de flora e fauna, uma ligação mineral, as articulações meteorológicas. Mas a paisagem move-se por dentro e por fora, encaminha-se do dia para a noite, vai de estação para estação, respira e é vulnerável. Ameaça-a o seu pró-
38. LOPES. A inocência do devir - ensaio a partir da obra de Herberto Helder, p. 35.

39. Para articular o conceito de "nó corpo-linguagem", de Silvina Rodrigues Lopes e a "corpografia simbólica, simbologia corporal", de $\mathrm{HH}$, valho-me indiretamente do conceito lacaniano de letra. Podemos elaborar, a partir da leitura da obra de Lacan, o conceito de letra como resto de uma prática capaz de delimitar pontos de articulação e separação entre os excedentes energéticos do corpo somático e a linguagem, em seu funcionamento simbólico. Em seu texto "A letter, a litter", Ram Mandil apresenta uma interessante definição de letra referente à rede conceitual psicanalítica lacaniana, que nos permite pensar em que medida a letra indica, na língua, uma substância a ela distinta, sem representação, mas nela presente. Em termos lacanianos, indica o gozo em meio à língua: "E possível dizer que, em uma leitura retroativa, a letra, pensada como distinta do significante, seria o que, na ordem da linguagem, permitiria apreender a circulação dessa substância, dessa materialidade à qual Lacan gradativamente associa o gozo." (MANDIL. Os efeitos da letraLacan leitor de Joyce, p. 47.

40. HELDER. $A$ faca não corta o fogo p. 153.

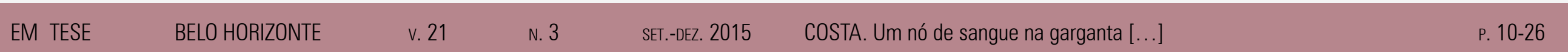


41. HELDER. Photomaton \& Vox, p. 33-134.

42. A respeito, ver: "Imanência e desejo" (DELEUZE; GUATARI. Imanência e desejo. In: Kafka: por uma literatura menor, p. 81-96.). prio fim de paisagem. Pela ameaça e vulnerabilidade é ela viva. E é também uma coisa do imaginário, porque uma paisagem brota do seu mesmo mito de paisagem. Aquilo que lhe firma a existência situa-se nas condições do desejo: o movimento entre nascença e morte. A tensão criada pela ameaça destruidora afiança-lhe a vitalidade. A árvore da carne ${ }^{41}$.

Entre nascimento e morte, o desejo, potência ou energia fundamental na obra de $\mathrm{HH}$, move-se do corpo à paisagem, da paisagem ao corpo: do poema ao poema, porque o poema é corpo e paisagem. A circulação do desejo é ela mesma o ofício de viver, o ofício de "arrancar à morte a vida". Se o poema é também uma paisagem, já não há separação entre interior e exterior. Poema, corpo e paisagem - um nó: “a árvore da carne”.

A árvore da carne - corpo e paisagem do poema ou poema e corpo como paisagem - se aproxima do que Deleuze conceitua plano ou campo de imanência ${ }^{42}$. Campo fora da representação, em que o desejo se movimenta metonimicamente por contiguidade de imagens, em constante metamorfose. Uma vida, a vida desprendida do indivíduo, criada na operação poética, habita esse campo, o campo de amarração entre corpo, poema e paisagem: nó imanente, fora da representação, articulando em texto uma vida desejante. Campo de tensão, já que o desejo, energia que vivifica o poema, corre a todo o tempo o risco de desaparecer, pois, lembremos, uma vida é o próprio movimento de dessubstanciar a morte e lançá-la ao movimento. Passar da morte substantiva à "morte no gerúndio".

Nos limites da linguagem, na substância lenhosa da árvore da carne, uma vida se faz na materialidade extrema da língua a qual assim Agamben descreve, no livro Ideia da Prosa:

\section{Ideia da matéria}

A experiência decisiva que, para quem a tenha feito, se diz ser tão difícil de contar, nem chega a ser uma experiência. Não é mais que o ponto no qual tocamos os limites da linguagem. Mas aquilo que então tocamos não é, obviamente, uma coisa, de tal modo nova e portentosa que, para descrevê-la, nos faltam as palavras: é antes matéria, no sentido em que falamos de 'matéria da Bretanha' ou 'entrar na matéria, ou ainda índice das matérias'. Onde acaba a linguagem, começa, não o indizível, mas a matéria da palavra. Quem nunca alcançou, como num sonho, esta substância lenhosa da língua, a que os antigos chamavam silva (floresta), ainda que se cale, está prisioneiro das representações. É como o caso daqueles que regressaram à vida depois de uma morte aparente: na verdade, de modo nenhum morreram (senão não teriam regressado), nem se libertaram da necessidade de ter de morrer um dia; libertaram-se, isso sim, da representação da morte. Por isso, interrogados sobre aquilo 
43. AGAMBEN. Ideia da Prosa, p. 29.

44. HELDER. Photomaton \& Vox, p. 8.

45. DELEUZE; GUATARI. Imanência e desejo. In: Kafka: por uma
literatura menor, p. 93.

46. BLANCHOT. $A$ parte do fogo, p. 323 que lhes aconteceu, não têm nada a dizer sobre a morte, mas encontram matéria para muitas histórias e para muitas belas fábulas sobre a sua vida ${ }^{43}$.

Onde a linguagem já não mais representa, mas se apresenta como matéria de início, palavra vegetal e corpórea, o cerne da experiência - a constituição de um corpo e uma paisagem no poema - se revela, como "uma frase cosida ao fôlego, ou um relâmpago/ estancado/ nos espelhos." ${ }^{44} \mathrm{Na}$ experiência do poema, abertura ao "campo ilimitado de imanência" ${ }^{45}$, uma vida, liberta da individualidade, liberta-se também da representação da morte. "Mas a linguagem é a vida que carrega a morte e nela se mantém" ${ }^{46}$. No poema, espaço da metamorfose, uma vida, portanto, está a salvo da morte. Porque, vivendo, está permanentemente entregue ao ofício de viver a morte, no gerúndio.

\section{A TRADUÇÃO DO POEMA}

Mencionei anteriormente a estrutura reticular da obra de $\mathrm{HH}$ e as estratégias de leitura que me parecem adequadas à leitura que proponho. Entendo, neste texto, por obra, não apenas o que está escrito ou a reunião dos textos publicados, mas a articulação necessária entre esses textos para a composição de um conjunto dinâmico de nós textuais, em que cada elemento se correlaciona a todos os outros, em um sistema de circulação energética.
Nessa perspectiva global, podemos pensar a tradução na poética do autor como elemento da composição da própria obra. Porque, em HH, tradução e escrita se aproximam de tal forma que já não se emprega o termo "poema traduzido", mas "poema mudado". Refiro-me aos "poemas mudados para o português", série composta pelos livros O bebedor noturno (1986), As Magias (1987), Ouolof (1997), Poemas Ameríndios (1997) e Doze nós numa corda (1997). Nessa série, o autor traduz, de modo muito próprio à sua poética, poemas de culturas extremamente diversas, vindos de partes distintas do mundo, atravessando períodos que remontam à escrita bíblica do Cântico dos Cânticos, passam por antigos ritos e cantos tribais indígenas e africanos, por poetas ocidentais e orientais e poetas mais recentes, como Henri Michaux e Le Clézio.

João Amadeu Oliveira, em uma nota etimológica, apresenta uma interessante hipótese a respeito da técnica empregada nos poemas mudados: "De algum modo $[\mathrm{HH}]$ assumiu a amplitude do verbo 'traduco' do latim , utilizando-o no sentido de conduzir para o outro lado, fazer passar (dum lado ou de um estado para outro). Deste modo, traduziu-o, até porque ao passá-lo para outro contexto, o poema deixou já de ser o mesmo." ${ }^{47}$ Os poemas mudados são, assim, como enxertos: um poema estrangeiro que se insere na paisagem do poema próprio. O poema estrangeiro como muda, broto transposto
47. SILVA. $A$ poesia de Herberto Helder - Do contexto ao texto: uma palavra sagrada na noite do mundo, p. 168 
48. HELDER. Photomaton \& Vox, p. 69 .

49. HELDER. As Magias - alguns exemplos: poemas mudados para o português, p. 17

50. HELDER. As Magias - alguns exemplos: poemas mudados para o português, p. 16 de uma a outra obra, segundo o prazer e o trabalho com a matéria textual, com a substância lenhosa da língua. Em "O bebedor noturno", texto de mesmo nome de um dos livros dos poemas mudados, $\mathrm{HH}$ explicita seu procedimento:

O meu prazer é assim: deambulatório, ao acaso, por súbito amor, projetivo. Não tenho o direito de garantir que esses textos são traduções. Diria: são explosões velozmente laboriosas. O meu labor consiste em fazer com que eu próprio ajuste cada vez mais ao meu gosto pessoal o clima geral do poema já português: a temperatura da imagem, a velocidade do ritmo, a saturação atmosférica do vocábulo, a pressão do adjectivo sobre o substantivo ${ }^{48}$

Em As magias, há um poema de Henri Michaux mudado para o português, que nos permite perceber o ponto nevrálgico sobre o qual incide a operação "tradutória". Um ponto de enodamento material, articulando língua e paisagem. Trata-se do poema "Iniji", escrito parte em língua francesa mudado para o português, parte em grafias da voz exterior a qualquer língua: "orrenaniâã Iniji/ e Iniji inanimada"49. Espécie de língua arcaica, se por arcaico entendermos próximo da origem (arké). Lembremos, uma língua é, em sua origem, em seu caráter mais elementar, som, ritmo e desenho.

Nessa língua sem território fixo, "Movem-se margens/ Fundações afundam-se" ${ }^{50}$. Poderíamos aqui pensar na pura língua (die reine Sprache) $)^{51}$ benjaminiana, de seu "A tarefa do tradutor”. Linguagem originária, livre de qualquer sistematização prévia, absurdamente literal. Língua entre-línguas, que deixa marcas na materialidade de cada uma delas: na sonoridade, no ritmo e na imagem. Proponho tal aproximação porque, nas palavras do poema de Michaux, "Iniji fala com palavras/ que não são as suas palavras" ${ }^{2}$. Traduzir um poema cujas palavras importam menos que sua sugestão sonora e rítmica obriga a trabalhar com o corpo a substância física da palavra, tocando outro corpo linguístico. Porque, em tradução de poesia, "Um corpo tem a lembrança excessiva de outro corpo" ${ }^{\prime 3}$.

No mesmo livro, há a tradução de um texto de Le Clézio, “- Um poema (Iniji) que não é como os outros -", que é uma leitura atravessada pelo poema de Michaux. Nele se lê:

Não é como os outros, este poema, não distrai, não se esquiva. Na verdade não está escrito, encontra-se ali na página por acidente, e deve estar também algures, gravado numa árvore, por exemplo, ou inscrito na terra seca, ou tatuado então na pele humana. Claro que não está apenas escrito Passou pelo tremor da escrita, foi assim que apareceu primeiro. Mas não existe somente nesse tremor, não existe somente para os olhos. Existe algures, em volta, no ar, nas nuvens, nas folhagens das árvores vistas à distância, no mar, na erva calcada de uma pista. E nas ruas de uma grande cidade,
51. A respeito da pura língua, ponto a ser visado na tradução, Benjamin escreve em "A tarefa do tradutor": "Essa liberdade (da tradução) não deve sua existência ao sentido da comunicação, do qual justamente a fidelidade tem a tarefa de se emancipar a tradução. Mais do que isso, essa liberdade se exerce, em nome da pura língua, na própria língua. A tarefa do tradutor é redimir, na própria, a pura língua, exilada na estrangeira, liberar a língua do cativeiro da obra por meio da recriação [umdichtung]. Em nome da pura língua, o tradutor rompe as barreiras apodrecidas da sua própria língua." (BENJAMIN. Escritos sobre mito e linguagem, p. 117.)

52. HELDER. As Magias - alguns exemplos: poemas mudados para o portugues, $\mathrm{p} .18$.

53. HELDER. As Magias - alguns exemplos: poemas mudados para o português, p.17. 
54. HELDER. As Magias - alguns exemplos: poemas mudados para o português, p. 10-11.

55. HELDER. As Magias - alguns exemplos: poemas mudados para o português, p. 10 entre as paredes dos prédios, acompanhando o movimento dos automóveis, os cláxons, as luzes, a multidão ${ }^{54}$.

O poema está na paisagem, é ela própria. Está na lembrança excessiva de um corpo em outro, é energia de circulação entre a paisagem do corpo e do texto. Vai deixando marcas na pele, nas cascas de uma árvore, na superfície do papel. E a quem escreve, lê e transporta o poema de um lugar ao outro, cabe acompanhar sua música: "Agora, depois de Iniji, já não interrogamos. Há uma certeza. Viu-se qualquer coisa, seguiu-se essa coisa, como se a gente estivesse a fazê-la, como se tivesse encontrado ouvidos para escutar a música do fundo da água. ${ }^{15} \mathrm{O}$ poema se escreve, se lê e se traduz seguindo a música submersa que há não na língua estruturada, mas na música que evoca, música submarina que ecoa no poema. Para Herberto Helder, ao traduzir os dois textos em torno dessa outra língua, a de Iniji, é preciso atentar-se não em suas palavras, mas na música de que deriva.

A leitura de Le Clézio, traduzida por $\mathrm{HH}$, acontece, portanto, como se algo estivesse sendo feito no ato de ler/mudar para o português. Ler, traduzir, seguindo, criando a, digamos assim, pura língua de Iniji. Língua entre traduções, fora do registro comunicativo, fora da lógica arregimentada por gramáticas e sentidos relativamente já cristalizados por dicionários. Diferenciação interna à língua, ligada ao corpo, de onde nascem os poemas:
Claro, considerávamos importantes essas palavras da linguagem, essas palavras comuns. Excitadas como matilhas, boas para caçar, farejar, ladrar, matar. Mas há outra língua, que falávamos antes de nascer. Uma língua muito antiga, não servia para nada, não era a língua do comércio com os homens. Não era decerto uma língua de sedução, para subornar, ou para dominar. Dela provinham as palavras, estas palavras: fluidos, vento, bilha, órfã, carris, dormir, coração, constelada, cisne, lasciate, vapor, contorno, opala, vem... Existiam ao mesmo tempo que a vida, não desligada dela. Eram uma dança, uma natação, um voo, eram movimento ${ }^{56}$.

Falar de Iniji é um exercício de aproximação da forma pura da sonoridade, é como reproduzir gestos, movimentos da língua antes de pronunciar a primeira palavra. Elemento à margem da língua. Palavras informuladas que se esquecem em meio aos usos da língua, mas são "lembradas" no exercício de leitura/tradução: “Tínhamo-las perdido de vista. Depois, hoje, reencontradas, são elas que me reencontraram, e me obrigam a lembrar." ${ }^{57}$ Uma vez atingido esse cerne poético, que se exibe nos poemas de $\mathrm{HH}$, sejam eles os mudados para o português ou não, o poeta pode dizer: "Já não pretendemos falar todas as línguas. As palavras encontram-se além sempre além, e é preciso apanhá-las depressa. As vogais que soam, ressoam." ${ }^{58}$ Certa inocência em relação às línguas passa a ser a técnica de captar as palavras estrangeiras por sonoridade e sugestão: "Quanto a mim não sei línguas. Trata-se de minha vantagem." 59
56. HELDER. As Magias - alguns exemplos: poemas mudados para o português, p. 12-13.

EM TESE

BELO HORIZONTE

v. 21

N. 3

SET.-DEZ. 2015

COSTA. Um nó de sangue na garganta [...]

P. $10-26$

57. HELDER. As Magias - alguns exemplos: poemas mudado para o português, p. 13 .

58. HELDER. As Magias - alguns exemplos: poemas mudados para o português, p. 14

59. HELDER. Photomaton \& Vox, $\mathrm{p}$. 68 
Parece ser esse um dos principais pontos da articulação da poética helderiana a outras: a tradução em que se mudam poemas, operando no corpo da linguagem, sem que haja aí qualquer metáfora. Trata-se de um estilo que equaciona poéticas por diferença, articulando o que nelas é por si só um elemento de diferença: o som, o movimento, o ritmo, a imagem. Articulação de poéticas por imparidade, não por pareamento. Talvez seja esse o dom das línguas, que confina com a singularidade de uma assinatura. Não por acaso, é essa a direção, que se explicita em um de seus poemas de $A$ faca não corta o fogo:

mas eu, que tenho o dom das línguas, senti

a linha sísmica atravessando a montagem das músicas,

e ouvi chamarem-me em lírica,

numa língua nenhuma que não sabia,

e os acertos e erros do meu nome não eram traduzíveis

nas línguas do meu dom,

e soube então que ar e fogo se mantinham um ao outro mas,

em vez de se abrirem,

se fechavam, e estremeci das músicas ¿oh

o que eram elas,

que coisa grande traziam para ser posta em mínimo,

e que somenos ministério lavrava assim que voz

no vivo,

no arrepio do ritmo por brônquios, garganta e dentes,

para fora,

para o escuro,

para o número ímpar?

Nesse lugar, em que se exibe a linha sísmica atravessando a montagem das músicas, o lugar entre poéticas dispostas em diferentes épocas e espaços, o ritmo transporta, quem sabe, não apenas os sons, os sentidos e suas interrupções, mas também as ressonâncias da origem, no sentido grego da arké. Linha sísmica em que o arcaico faz ressoar uma origem: a da palavra. Lembremos aqui das palavras de Agamben:

a contemporaneidade se escreve no presente assinalando o antes de tudo como arcaico, e somente quem percebe no moderno e recente os índices e as assinaturas do arcaico pode dele ser contemporâneo. Arcaico significa: próximo da arké, isto é, da origem. Mas a origem não está situada apenas num passado cronológico: ela é contemporânea ao devir histórico e não cessa de operar nesse como o embrião continua a agir nos tecidos do organismo maduro e a criança na vida psíquica do adulto ${ }^{61}$.

Aí, nesse espaço, a poesia portuguesa, nas mãos, na assinatura de Herberto Helder, atualiza-se a todo tempo, ao fazer ressoar no texto próprio a língua para sempre estrangeira, entre a sua e a outra poética. Retomemos um dos nós
60. HELDER A faca não corta o fogo, p. $169-170$. 
fundamentais deste texto, como quem o arremata, para concluir: "O talento de saber tornar verdadeira a verdade. // Chega a mão a escrever negro e conforme vai escrevendo mais negra se torna." ${ }^{62}$

\section{REFERÊNCIAS}

AGAMBEN, Giorgio. Ideia da Prosa. Lisboa: Edições Cotovia 1999

\section{AGAMBEN, Giorgio. O que é o contemporâneo e outros} ensaios. Chapecó: Argos, 2009.

BARTHES, Roland. O óbvio e o obtuso. Tradução de Léa Novaes. Rio de Janeiro: Nova Fronteira, 1990

BENJAMIN, Walter. Escritos sobre mito e linguagem. São Paulo Editora 34, 2011

BLANCHOT, Maurice. A parte do fogo. Rio de Janeiro: Rocco, 1997.

BLANCHOT, Maurice. O espaço literário. Tradução de Álvaro Cabral. Rio de Janeiro: Rocco, 1987.

COELHO, Eduardo Prado. A poesia ensina a cair. Lisboa: Imprensa Nacional - Casa da Moeda, 2010.

C, E G. acurar-se da escrita. 2014. Tese (Doutorado em Teoria da Literatura e Literatura Comparada) - Faculdade de Letras, Universidade Federal de Minas Gerais, Belo Horizonte, 2014
DELEUZE, Giles; GUATARI, Félix. Imanência e desejo. In

Kafka: por uma literatura menor. Belo Horizonte, São Paulo: Autêntica, 2014.

DELEUZE, Gilles. L'imanence: une vie... Philosophie, Paris, n. 47 set. 1995, p. 3-7. Tradução de E G C e João Rocha.

REUD, Sigmund. Além do princípio de prazer. In: Freud online. Disponível em: http://www.freudonline.com.

$\mathrm{br} /$ ?s $=\mathrm{Al} \% \mathrm{C} 3 \% \mathrm{~A} 9 \mathrm{~m}+$ princ\%C3\%ADpio + prazer. Acesso em: 19 nov. 2015

GUEDES, Maria Estela. A obra ao rubro de Herberto Helder. São Paulo: Escrituras, 2010.

HELDER, Herberto. A faca não corta o fogo. Lisboa: Assírio \& Alvim, 2008

HELDER, Herberto. A morte sem mestre. Porto: Porto Editora, 2014

HELDER, Herberto. As Magias - alguns exemplos: poemas mudados para o português. Lisboa: Assírio \& Alvim, 2010.

HELDER, Herberto. $\mathbf{O}$ bebedor noturno - poemas mudados para o português. Lisboa: Assírio \& Alvim, 2010.

HELDER, Herberto Os passos em volta. Porto: Porto Editora 2014

HELDER, Herberto. Photomaton \& Vox. Porto: Porto Editora (Assírio \& Alvim), 2013. 
HELDER, Herberto. Poemacto. In :

A faca não corta o

fogo. Lisboa: Assírio \& Alvim, 2008.

HELDER, Herberto. Poemas canhotos. Porto: Porto Editora, 2015.

HELDER, Herberto. Servidões. In

Porto: Porto Editora, 2014

Poemas completos.

KAFKA, Franz. Essencial Franz Kafka. São Paulo: Penguin

Classics Companhia das Letras, 2011.

LACAN, Jacques. O seminário, livro 10: a angústia. Rio de Janeiro: Jorge Zahar, 2005

LOPES, Silvina Rodrigues. A inocência do devir - Ensaio a partir de Herberto Helder. Viseu: Edições Vendaval, 2003.

MANDIL, Ram. Os efeitos da letra - Lacan leitor de Joyce. Rio de Janeiro/Belo Horizonte: Contra-Capa Livraria/Faculdade de Letras da UFMG, 2003

SILVA, João Amadeu Oliveira Carvalho da. A poesia de Herberto Helder - Do contexto ao texto: uma palavra sagrada na noite do mundo. Lisboa: Fundação Calouste Gulbenkian - Fundação

para a Ciência e a Tecnologia, 2004. 